\title{
Educating Anglicans: A case study investigating group work in the Church of England
}

\begin{abstract}
Author:
Roger Grainger ${ }^{1,2}$

Affiliations:

${ }^{1}$ GST Academic Board and holding the Permission to Officiate (PTO), Anglican Diocese of Wakefield, United Kingdom
\end{abstract}

${ }^{2}$ Faculty of Theology, North-West University, Potchefstroom Campus, South Africa

\section{Correspondence to:} Roger Grainger

Email:

roger@gschooltheol.com

\section{Postal address:}

Fuchsia Cottage,

Corraunbuoy, Newport,

Co. Mayo, Republic of Ireland

\section{Dates:}

Received: 25 Nov. 2013

Accepted: 26 June 2014

Published: 10 Dec. 2014

How to cite this article: Grainger, R., 2014, 'Educating Anglicans: A case study investigating group work in the Church of England', In die Skriflig 48(1), Art. \#1784, 7 pages. http://dx.doi. org/10.4102/ids.v48i1.1784

\section{Copyright:}

(C) 2014. The Authors.

Licensee: AOSIS

OpenJournals. This

work is licensed under the Creative Commons

Attribution License.

\section{Read online:}

Scan this QR code with your smart phone or mobile device to read online.
The dominant form of group work in the Church of England is educational and directive. An investigation was carried out to determine whether other forms of group work could be valuable for the Church in addition to this approach. The same group of nine members, members of two Church of England parishes in the North of England, were involved in 12 sessions of group work, four sessions of each of the three types of group structure, in order for them to report their individual reactions to each type. An Interpretive Phenomenological Analysis (IPA) showed that all three kinds of groups drew attention to four principle areas of comment. In all these kinds of groups, belonging, safety, enrichment and personal validation, with each one of the three groups scoring more highly than the other two on one or other of these dimensions. No group showed itself as more directly educational than the others, showing that, for church educational purposes, a range of group structures may be used as actual learning comes from the experience of group membership itself. Using the qualitative research model of IPA, an investigation was carried out into the principal themes emerging from members' self-reports concerning their experiences of the three different group structures, revealing four value constructs - belonging or alienation, safety or danger, enrichment or impoverishment and validation or rejection - which played a dominant role in all three kinds of groups. Taken together, each of the three group structures gave a different degree of prominence to each of the four evaluative constructs so that each of the three was shown to be particularly relevant for, and associated with, a particular area of experiential learning.

Die onderrig van Anglikane - 'n ondersoek na groepwerk in die Kerk van Engeland: 'n gevallestudie. Die belangrikste vorm van groepwerk in die Kerk van Engeland is opvoedkundig en rigtinggewend van aard. 'n Ondersoek is gedoen na die waarde van bykomende metodes van groepwerk. Dieselfde groep van nege lede uit twee gemeentes in die Noorde van Engeland, was by die 12 groepwerksessies betrokke - vier sessies vir elk van die drie tipes groepstrukture - om hulle in staat te stel om hulle onderskeie reaksies op elkeen van die tipes groepstrukture te rapporteer. ' $n$ Interpretiewe fenomenologiese analise het aangetoon dat al drie tipes groepstrukture die soeklig op vier hoofkenmerke laat val het, naamlik om te behoort, veiligheid, verryking en bevestiging van eiewaarde. By elke groep het een of meer van hierdie kenmerke swaarder geweeg as by die ander twee groepe. Geeneen van die groepe het opvoedkundig meer as die ander uitgestaan nie, wat bewys dat 'n reeks groepstrukture vir kerklike opvoedkundige doeleindes gebruik kan word, aangesien leer in wese uit die ervaring van die groeplede self kom. Met behulp van die kwalitatiewe navorsingsmodel van die interpretiewe fenomenologiese analise is ondersoek ingestel na die hooftemas soos blyk uit die lede se individuele verslae ten opsigte van hulle ervaring van die drie verskillende groepstrukture. Die verslae het vier waardekonsepte openbaar wat ' $n$ dominante rol in al drie tipes groepe gespeel het, naamlik om te behoort of te vervreem, veiligheid of gevaar, verryking of verarming, en bevestiging van eiewaarde of verwerping. Samevattend blyk dat die drie groepstrukture elkeen ' $n$ ander graad van prominensie aan die vier verskillende waardekonsepte toeken sodat elke groep spesifiek relevant is vir en geassosieer word met 'n spesifieke area van ervaringsleer.

\section{Introduction}

\section{The background to the study}

During the last ten years, the Church of England in the UK has put an increasing amount of effort into the education of its churchgoing members as far as the nature and terms of their membership are concerned. This activity concentrated on the use of shared learning, as opposed to learning in classrooms or lecture theatres. In the past, these groups were usually left to individual parishes 
to arrange. Now they are often regulated by a central authority, usually the Diocesan Office, which has issued courses of study with accompanying 'guide-lines' as to how they should be conducted (Archbishops' Council 2005/2009). The courses are usually extensive and detailed with an emphasis on cognitive understanding rather than experiential learning. The emotional components within the group work process are not taken into account. Almost without exception, these are directive in intention.

In view of the range of different kinds of group work available, there is reason to believe that the current scope of group work within the Church of England may not be wide enough. There is little evidence in the material cited of awareness of the value to congregations of involvement in the group process itself as a medium for personal development (Corey \& Corey 1997; Ottaway 1966; Yalom 1995). Similarly, the important advances in understanding group experience, spearheaded by the arts therapies, are completely ignored (Grainger 1990; 1999; Jennings 1990; Jones 2004; Pitruzzella 2004; 2009).

At the same time, we were particularly interested in the ways in which churches set about their evangelistic task of deepening the personal involvement of their members (Grainger 2002, 2003). There are several fundamentally different types of human groups, but, by concentrating on an approach, which depends on instruction rather than discovery, it appears that the Church of England (and perhaps other Christian bodies too) may be neglecting the possibility that other, more experiential and less didactic kinds of group work may more effectively educate its members in Christian belonging. Process-orientated training groups and art-therapies approaches, that is, groups in which members learn from observing their relationships with one another and those that use art as a medium for personal encounter, are two examples of different educational paradigms that are less cognitively directed. Amongst process-orientated theorist-practitioners, Yalom (1995), Ottaway (1966), and Corey and Corey (1997) direct special attention is given to the beneficial effects of group work for personality development. Grainger (1990), Jennings (1990), Jones (2004) and Pitruzzella (2009) point to the liberating effect of the art therapies upon personal relationships. A comparison amongst these three kinds of group work (directive, process-orientated and art-based), the first leaderdirected, the other two group-led, would possibly be able to open up new avenues for congregational group work in educating members in Christian belonging.

\section{The aim of the investigation}

The research questions were quite straightforward: How may directive and experiential group work affect group members and be used successfully in educating members of the Church of England? What would a comparison between different kinds of group work reveal about the differences in their overall effect upon group members? How could such a comparison be made? Finally, what model may be proposed regarding educational group work in the Church of England and other church settings?

Discovering how directive and experiential approaches affected group members during educational group work or group training would involve arriving at an operational basis for distinguishing between group work approaches to directive learning and experiential learning. A research instrument had to be designed to compare these two categories and organise the necessary groups for doing so. Examples of the three kinds of group work chosen for comparison are given below, taken from members' protocols.

\section{Directive group}

The written material (Transforming Lives [2] 'Caring for each other') was followed, led by Roger. Nine people were present. There was a genuine sharing of reflection on times when the group members felt cared for. Scriptural passages were read as directed. Pastoral care was discussed honestly and openly - most group members contributed animatedly to the discussion. Many individual incidents were described in a free and honest manner; the group felt safe and inclusive. The material was adhered to and several people commented that they had found the session interesting. People were beginning to make connections and complement each other. A volunteer was quickly forthcoming and the issues around 'The Revelation' were conjectured upon. The basis of shared faith brought considerable consensus whilst instituting a space for consideration. Issues to think about and feedback to the church were discussed quickly, and the worship was carried out with due reverence. The grace was said as everyone held hands, making it a concrete group. A coffee or tea-break had been mooted at the beginning of the group session. After what seemed like a short time, Roger asked if people wanted a tea-break. The consensus was that we should continue to complete the piece and forego a tea-break.

\section{Process group}

There were 12 people present, including one new member and one back from holiday. The beginning was a small recap to inform the new member and the rest of the group of the purpose and function of the session: to build a group by coming together and drawing strength from being in a group. The first task, then, was to talk about something interesting since we last met. Everyone in the group participated, some with serious concerns that seemed difficult to solve practically, some with genuinely happy and joyous situations that they felt they could share. Everyone was intensely interested in each individual's participation. The theme of the session, Roger (the leader) said, was going to be about sharing and bearing each other's burdens. A discussion took place, reiterating that it is often necessary to accept that there is no answer to life's trials, but at least, we can empathise and understand the perspective of the individual. After several contributions, the general consensus was that it is really important to receive permission from others to express what 
we feel. This led on to trusting in God and giving it all to him. The fundamental question of betrayal was then aired people sometimes let one down and betray your trust: Jesus was betrayed by the people he loved. Several members of the group were in awe of the fact that God, through Jesus, can feel as we do, yet still forgive and reinstate people in the previous relationship. A break for tea occurred here, and Roger was quite firm in allocating time for a change in focus. This allowed people to break into smaller groups and talk animatedly about issues that had been brought up for them in the previous discussion. Then, the issue of male and female contributions in sharing emotions was discussed with different contributions and perspectives on the norms and mores of society.

\section{Art-based}

The intention was to have no chairs and to explore the space. Roger asked us to walk around not speaking to anyone, then to say 'Hello' and begin to make contact. People entered into this - grounding them, and then making contact with the group. Next, two small groups were formed. We were to think up a scenario and present it to the other group.

The theme was offering help and having that help rejected or being helped ourselves.

There were five people in each group, and the process of deciding on a scenario and putting it together was obviously different for each group. Two group presentations took place:

1. A young mother with a child, refusing to answer the door or accept any help. Many different officials summoned and attempts made, but eventually both mother and child were dead.

2. Two young prostitutes approached by a person trying to make contact and offer help. Although the girls took the chocolate he pressed on them, they refused to connect or interact.

(At this point we had a break, during which we were not meant to discuss the previous depictions. This proved very hard!) Next, discussion took place of the circumstances presented in the depictions. Roger brought in the theme of the Good Samaritan, and we each read out a sentence from the story. Roger then asked us to write down two excuses or apologies, which the Levite or the Priest might have made along with what the Samaritan may have had in mind before helping. All the group members participated, using their imaginations to pull the situation in the parable into a contemporary context. This involved some spontaneous prayers, and we finished with the Lord's Prayer, holding hands to say the Grace.

\section{Choosing the method}

The researchers spent time searching for ways of looking at group work from the inside, which meant taking account of it as a human phenomenon. This includes investigation as a participant and not as a detached observer - a status which is theoretical rather than real and distracts from the reality of the actual experience. The phenomenological approach has been described as '... a means for getting at the directness of experience through the reconstruction of language possible to the experience' (Natanson 1978:195). This is language produced by experience itself, emerging from experience as a direct response to experience by going more deeply into experience instead of extending it by association with a string of other ideas or feelings. This is the process phenomenologists refer to as 'reduction', which is a way of discovering what something is really like by isolating ('bracketing') it from other considerations, specifically, as far as possible, from material, which does not characterise this particular experience. In order to do this, the process of phenomenological analysis is one of narrowing down the original evidence regarding an experience in order to disclose what it was actually like, apart from the meanings, which have become attached to it.

With regard to the present investigation, the data itself, in the form of ideas and feelings, opinions and judgements expressed by participants, becomes progressively more concentrated in a way which preserves its meaning whilst clarifying the underlying structure. Analysis is directed throughout the reduction process towards the discovery of areas of experience responsible for the actual things. All the time, the investigator's attention is directed towards understanding what subjects themselves feel to be most important, most in need of expression, rather than interpreting the material according to their own preconceived ideas.

In its approach to understanding the reality of ordinary human experience, phenomenology shuns clinical (pathology-based, rigorously scientific) techniques and turns its attention to everyday examples of the lived world such as Husserl's Lebenswelt, to which life as a member of a group belongs. Alfred Schütz (1966) describes the Lebenswelt [life world] as the sphere in which:

$[\ldots]$ in the natural attitude we, as human beings among fellow human beings, experience culture and society, take a stand with regard to their objects, are influenced by them and act upon them. (p. 118)

In this way it aims to make explicit the meanings, which we attach to the world in which we live and the things we do, think, feel and intuit within it. Phenomenologically oriented researchers concentrate on how things feel to people, because this is a principal - even the principal - ground of their attitude towards them, which, in turn, governs the way they understand and act towards them.

Consequently, an experiment was designed in order to determine whether a small group of people, who had expressed willingness to be involved in groups designed in these three separate ways - directive, process-orientated and art-based - and to say or write down what taking part in them felt like at a personal level, would provide 
information regarding their differential value for the purpose of continuing congregational training within the setting of Church of England parishes (or any similar circumstances concerning Christian education). In other words, could we measure quality of experience rather than behavioural effects? Could we assess the impact on individuals of an experience of sharing something, which happens between people and resists attempts to reduce it to its constituent parts?

Obviously this had to be done in as open and unbiased a way as possible, taking care to allow the people concerned to ask their own questions so that the enquiry's results would reflect each individual's prejudices, not simply those of the experimenter.

The aim, then, was to design an experiment to explore rather than demonstrate. Whether the conclusions eventually drawn would be definite enough to add weight to the proposal or not, it would be worth putting things to the test, particularly as this is an area in which there has been no previous systematic attempt to explore different kinds of small-group structure in a way which strives to be impartial.

The qualitative research paradigm, IPA, is a reversal of quantitative psychological research procedure in that an interpretation is derived from studying people's experience of a state of affairs (the phenomenon) instead of starting with a possible explanation (an interpretation) and manipulating the circumstances surrounding the phenomenon in order to determine the explanation. In IPA, data consists of recorded experiences of a phenomenon, using a range of techniques involving open-ended enquiry and depending on personal testimony. The stance of those conducting the enquiry is curious and facilitative (see Colaizzi 1978).

Smith, Jarman and Osborn (1999) point out that the approach aims to discover the views of individuals who are themselves involved in a particular situation. This can, however, never be done in a precise way as those who are observing others' reactions or listening to their testimonies regarding the quality of their experience, which are equally subject to their own ideas and attitudes of mind. The observers actually need these experiences in order to make any sense of the personal universes to which they are being granted access. Interpretation is always necessary in order to make sense of anything about which we intend to learn. This is why analysis is also 'interpretative' and must always admit to being so. IPA represents a conscientious intention to make sense of what people are actually saying in the way that those people themselves actually mean it. This is why any theorising about what they mean must wait until what they have said or written down has been analysed in order to find out what they themselves are actually intending to convey. Although this can never be done precisely, owing to our own preconceived ideas, it is preferable to using those ideas in advance, trusting in our own ability to demonstrate that we have been right all the time. As far as human beings are concerned, 'educated guesses' should wait upon the attempt to understand what it is that we are actually dealing with when there is a possibility of drawing realistic conclusions about what people were thinking and feeling within an actual situation. IPA, say Smith et al. (1999):

[...] while recognising that a person's thoughts are not transparently available from, for example, interview transcripts, engages in the analytic process in order, hopefully, to be able to say something about that thinking. (p. 219)

Material for enquiry is generated by a systematic accumulation of first-hand accounts of an experience given by those involved in it. The effort put into carrying out this kind of research consists in making sure that conclusions drawn are kept flexible until all the evidence has been considered as a totality and the appropriate cross-currents within it can be included within the account which finally comes to be drawn up. Smith et al. (1999:224) remind us that '[a]nalysis is a cyclical process,' going on to say that investigators should '[...] be prepared to go through the stages a number of times, dropping a subordinate theme if a more useful one emerges'.

The themes which are identified are not actually present in the material being studied in any concrete or objective sense, but emerge from it as an underlying message addressed to the investigator. This may sound suspicious to those who depend on things being dependent upon their own concreteness, but our understanding of one another is always far from literal. IPA parts company with nomothetic approaches in order to take account of this fact, which is vitally important for understanding human experience in a realistic way. The categories distinguished must be ones which apply to all participants in the enquiry. It means that generalisability takes precedence over precision. Material, which the scrutiniser identifies as evidence regarding the state of mind of one particular person, but which finds no echo elsewhere in the group, must not be allowed to affect the choice of themes regarding the group as a whole although it remains part of their data for the experiment and its presence must be mentioned when the exercise is written up. An example of this occurred when one group member mentioned the educational value during one of the process sessions. (This was the only time that the subject arose despite the fact the members had been instructed that all three kinds of groups were learning groups!) Whatever seems important for the experiment, even opinions, feelings and attitudes, which only impinge on one or two members, affects the state of mind of whomever it is that is drawing conclusions regarding the investigation as a whole and this, in the long run, is the salient factor.

Our investigation into group work, aimed at arriving at a final 'master list' of themes which corresponds to the overall experience of the group, is revealed in 'the identification of shared themes across participants' accounts'. The emphasis throughout is on meaning rather than measurement, the identifying characteristic of qualitative as opposed to quantitative research. 
TABLE 1: Occasions on which themes occurred in members' protocols.

\begin{tabular}{|c|c|c|c|c|c|c|c|c|c|}
\hline \multirow[t]{2}{*}{ Groups } & \multicolumn{2}{|c|}{ Theme 1} & \multicolumn{2}{|c|}{ Theme 2} & \multicolumn{2}{|c|}{ Theme 3} & \multicolumn{2}{|c|}{ Theme 3} & \multirow[t]{2}{*}{ Total } \\
\hline & Belonging & Alienation & Safety & Danger & Enrichment & Impoverishment & Validation & Rejection & \\
\hline Directive & 4 & 6 & 7 & 8 & 14 & 8 & 6 & 5 & 58 \\
\hline Process & 12 & 11 & 7 & 6 & 14 & 9 & 11 & 5 & 75 \\
\hline Art-based & 12 & 4 & 6 & 11 & 19 & 15 & 13 & 6 & 86 \\
\hline Total & 28 & 21 & 20 & 25 & 47 & 32 & 30 & 16 & \\
\hline
\end{tabular}

\section{The process of analysis}

This investigation consisted of nine sessions of group work, each session lasting for one and a half hours and arranged in accordance with one or other of three types of learning group structure: A (directive); B (process-orientated); C (art-based).

The sessions took place in the following order: A, B, C, B, C, A, C, A, B. The individual sessions are described in Grainger (2013).

Members submitted their impressions regarding the group sessions that they attended after the final meeting. These were then subjected to a phenomenological analysis involving a four-stage process:

Stage 1: group members prepare their written depositions

Stage 2: written material submitted for scrutiny

Stage 3: first analytical stage: themes identified

Stage 4: themes analysed to discover underlying structure.

Instructions had been given for submissions to be presented in the form of notebooks set aside for this purpose, but only half the members kept to this. The others used various ways of presenting their material. Attempts were made to include all the themes and to see which of them fell into 'natural' groupings, each of which represented the underlying reaction to a particular human experience. This is what Kelly (1991a; 1991b) identifies as a 'personal construct', expressing either the presence or absence of a particular quality of personal experience.

This way the number of individual themes was systematically reduced by a process of grouping together with those with similar meaning or implication. Because of their generalisability, the search for underlying concordance was extended to produce four themes perceived as underlying ones: validation, safety, enrichment and belonging. Apart from one member on one occasion, the theme of learning never came up even in the directive group sessions. The omission, however, simply indicated the presence of particular themes, giving no indication as to whether an individual group member remarked on the presence of a particular quality or its absence. Thus, the themes were scored according to the number of times a theme emerged, either as a positive or negative judgement, telling us about the groups themselves, based on individual members' experiences in them. Each of the four themes identified as salient is, of course, open to negative as well as positive expressions. In other words, it communicates absence as effectively as presence. The next step then was to compare the results with regard to the comparative salience of each of the four themes, whether its expression was positive or negative and how often a particular theme occurred (see Grainger 2013).

The final stage in the analytical process consisted in interpreting the material in its synthesised form in order to identify differential effects of varying structures for group work in the experience of those taking part in the 12 sessions. It became apparent that the art-based groups scored highest in two out of four thematic areas (enrichment/impoverishment and validation/rejection) and the process and directive groups in one area each (belonging/alienation and safety/danger). The process and art-based groups elicited three times as many positive comments as the directive groups with regard to 'belonging' and almost twice as many for 'validation'. The directive group work registered as more dangerous than process, but safer than art-based (Table 1).

No doubt more could be gained from further examination of the material. However, there is enough to demonstrate the importance of the four experiential themes and their interdependence. All four must be present in order for a group to function as an effective mode of shared learning. Each 'core theme' represents a dimension of awareness, which, through the holistic action of personal relationships, makes the others more salient. Together they live out a relationship that is diverse yet focused, social yet personal.

What the investigation appears to suggest therefore is that these particular reactions represent interpretative dimensions intrinsic to the experience of group work itself. The nine people who took part in the 12 sessions recorded experiences that highlight the importance of the four dimensions, which the analytic process elicited by successive levels of interpretative refinement. All nine group members expressed thoughts and feelings on these four subjects without reporting reactions that could reasonably be considered to be divorced from their scope. These were the things they considered worth mentioning about their experiences of the group work. Their protocols were as free and open as they themselves could allow them to be in circumstances where openness and freedom were actually stipulated as a requirement for taking part. All nine people, it emerged, had something to say regarding belonging, safety, enrichment and validation and the importance of these things to them.

The nature of the research model makes it impossible to state this as true of all group work, undertaken in any circumstances whatever. Certainly, it may be regarded 
as a theory open to further testing. However, the logic of Interpretative Phenomenological Research (Smith, Flowers \& Larkin 2009) leads us to regard it as an important piece of evidence contributing to the eventual emergence of a theory concerning group work experience.

Broadly speaking, directed groups drew least response in the way of written comment, and art-based groups most (58 as opposed to 86 ), with the process-orientated group work somewhat nearer to the art-based than to the directive (75). For spoken response therefore looseness of direction would seem to be more productive than tightness (always remembering, of course, that belonging to a group in itself suggests a structure for co-operation).

This is not to suggest that tightly constructed group work emerged as noticeably more effective for didactic purposes. Judging by members' depositions, cognitive learning came second to other things and did not play an important enough part in people's experience to be recognisable as an ongoing theme within any of the work. The 'enrichment' remarked on in this area had more to do with group interaction, the satisfaction in being together as a group and learning to know one another in the process than it had with the knowledge that they had been given any definite information. As in the other two kinds of groups, the things from the experience, which those taking part chose to record, were mainly feelings and intuitions - ideas emerging from life generated within the group itself.

What was being learned here was all about being in a group in this case a group of people with whom it sometimes felt safe to share quite intimate and personal thoughts and feelings. Consequently, the lesson was one about the safety in sharing.

Seeing that this was a group of church people - all but one of them members of the same denomination - the feeling of being complete strangers to one another was certainly not an intense one. The subject of a shared faith and heritage emerged frequently in these sessions, and even those members who were critical of the way some of their fellow group members believed, were willing to try hard to accept them as fellow followers of Christ. Instead of the fear of strangers, the initial threat lay in not feeling secure with people identifiable as dangerous friends. Safe within the written guidelines of the directive approach, with someone in charge who had the authority to make certain that these would be followed, members felt more protected and less exposed to the danger of saying more than they wanted to either about one another or about themselves.

Even so, the results showed a higher level of agreement within the three approaches regarding the dimension of belonging than for the others.

\section{Conclusion: Into the future}

The use of IPA revealed a shared dimension of group experience within the three group work formats. The degree to which each of the four group work themes was represented suggests that different structures contribute in their own way to the group solidarity on which effective group work depends. The salience of these four experiential categories suggests that particular group formats may not do as much as we expected to influence the success of groups, educational or otherwise. It also suggests that a successful group will be one that takes account of these four dimensions of human experience, whatever its official purpose may have been. If the Church of England concentrates on directive group work, because its purpose is to educate rather than simply provide group experience, this investigation suggests that directive groups may not be better at educating than other kinds of group work. In fact, our aim was to compare different kinds of groups in order to find out what each could contribute to Christian education. The answer appears to be that each of them contributes a particular stress on one of four dimensions characterising group learning.

Enough evidence emerged from this investigation to show that any assumption that only directive groups serve the interests of congregational learning, is at least questionable. If this being the case, concentration on directive modes of group work must involve a restriction of the overall value of groups for both individuals and organisations. All group work involves the risk of exclusion, frustration and the fear of being found wanting by others in the group. All group work offers the prospect of emotional wounding, even though this may often be recognised by the people concerned to have had a healing effect. It is also true that groups hold out a chance of a very positive kind of enrichment, the joy of being together, exploring life in the company of others with whom one begins to feel a special bond of fellowship. It is a risky thing, as one member said, to expose your feelings, opinions, convictions and abilities to others at such short range, but the opportunities for koinonia afforded for group work amongst church people are, in the words of another participant, 'mindblowing'. It is important to realise that the four dimensions were elicited and not supplied. They provided evidence of the importance of the degree to which participants felt at ease within the various kinds of groups setting, surely a vital factor in educational group work of any kind.

We should not be surprised to discover these themes claiming special significance for Christians who are engaged in learning to work through the difficulties involved in acting in close co-operation with others, particularly when the other group members are recognised as sharing not simply their common humanity, but also a common trust in God who is able to overcome all the forces, which can divide people against one another and ourselves against ourselves. The evidence presented here and the arguments produced in support of it suggest that there is more to be learned from, and taught by, group work than may be understood and appreciated by contemporary Christian churches. At present, it appears that, within the Church of England at least, group work remains largely unexplored territory. The scope of its usefulness within the overall work of the Kingdom makes it an opportunity, which is being missed. 
What is shown here as true about group work in a religious setting has relevance wherever the entrenched attitude to groups remains restricted to a directive format. After all, everyone learns more effectively when they are 'sitting comfortably'.

\section{Acknowledgements \\ Competing interests}

The author declares that he has no financial or personal relationship(s) that may have inappropriately influenced him in writing this article.

\section{References}

Archbishops' Council, 2005/2009, Shaping the future: New patterns of training for lay and ordained, formation for ministry within a learning church, Church House, London.

Colaizzi, P.F., 1978, 'Psychological research as the phenomenologist views it', in R.S. Valle \& M. King (eds.), Existential-phenomenological alternatives for psychology, pp. 48-71, Oxford University Press, New York, NY.

Corey, M.S. \& Corey, G., 1997, Groups: Process and practice, 5th edn., Brooks/Cole, Pacific Grove, CA.

Grainger, R., 1990, Drama and healing, Jessica Kingsley, London.

Grainger, R., 1999, Researching the arts therapies: A drama therapist's perspective, Jessica Kingsley, London.

Grainger, R., 2002, The beckoning Bible: A group work approach, Foundery, Peterborough.
Grainger, R., 2003, Group spirituality: A workshop approach, Brunner-Routledge, Hove. http://dx.doi.org/10.4324/9780203420355.

Grainger, R., 2013, Educating Anglicans: Investigating group work in the Church of England, Sussex Academic, Eastbourne.

Jennings, S., 1990, Dramatherapy with families, groups and individuals: Waiting in the wings, Jessica Kingsley, London.

Jones, P., 2004, The arts therapies: A revolution in healthcare, Hove, London.

Kelly, G.A., 1991a, The psychology of personal constructs: A theory of personality, vol. 1 , Routledge, London.

Kelly, G.A., 1991b, The psychology of personal constructs: Clinical diagnosis and psychotherapy, vol. 2, Routledge, London.

Natanson, M., [1967] 1978, 'Phenomenology as a rigorous science', in T. Luckmann (ed.), Phenomenology and sociology: Selected readings, Penguin, Harmondsworth.

Ottaway, A.K.C., 1966, Learning through group experience, Routledge \& Kegan Paul, London.

Pitruzzella, S., 2004, Introduction to drama therapy: Person and threshold, BrunnerRoutledge, Hove.

Pitruzzella, S., 2009, The mysterious guest: An enquiry on creativity from arts therapy's perspective, iUniverse, Bloomington, IN.

Schütz, A., 1966, 'Some structures of the life-world', in A. Schütz (ed.), Collected papers: Studies in phenomenological philosophy, vol. 3, pp. 116-132, Martinus Nijhoff, The Hague.

Smith, J.A., Flowers, P. \& Larkin, M., 2009, Interpretative phenomenological analysis: Theory, method and research, Sage, London.

Smith, J.A., Jarman, M. \& Osborn, M., 1999, 'Doing interpretative phenomenological analysis', in M. Murray \& K. Chamberlain (eds.), Qualitative health psychology, pp. 218-240, Sage, London.

Yalom, I.D., 1995, Theory and practice of group psychotherapy, 4th edn., Basic Books, New York, NY 